Emmanuel Lajus

Uniwersytet Mikołaja Kopernika, Toruń

ORCID: 0000-0001-7922-7256

e-mail: lajus@umk.pl

\title{
Moc twórczej Jaźni w filozofii Friedricha Nietzschego
}

\section{Wstęp}

Opierając się na rozwijanych przez Nietzschego pojęciach woli mocy i sensu, chciałbym pokazać, pod jakim względem twórcza Jaźń świadczy według niego o największej ludzkiej mocy, jaką jest tworzenie sensu na poziomie radykalnym. Zdaniem Nietzschego podstawowym faktem jest istnienie sił, które dążą do wzrostu poprzez zawłaszczanie lub opanowywanie innych, przezwyciężając opór otaczających sił․ Ten antagonizm jest absolutnie konieczny, ponieważ niepodobna zakładać istnienia siły

1 Nietzsche nazywa to podstawowe działanie sił „wolą mocy”. Por. Friedrich Nietzsche, Nachlass. Pisma z lat 1884-1885, przeł. Grzegorz Kowal (Warszawa: Wydawnictwo Naukowe PWN, 2011), 419-420: „wola mocy jest tym, co rządzi również światem nieorganicznym, bądź - co więcej - że nie ma świata nieorganicznego. Nie da się wyeliminować «oddziaływania na odległość»: coś przyciąga ku sobie coś innego, coś czuje się przyciągane. Oto fakt podstawowy [...]". Tłumaczenie G. Kowala: „oddziaływanie w dłuższej perspektywie” zmieniłem na "oddziaływanie na odległość", ponieważ w tym fragmencie Nietzschemu nie chodzi o perspektywizm. Cytuję dalej jako: N11. Por. Friedrich Nietzsche, NF-1885,34 [247], dostęp 8.03.2021, www.nietzschesource.org: „Die «Wirkung in die Ferne» ist nicht zu beseitigen". 
bez innej siły, na którą ona działa i która z konieczności działa na tę pierwszą - siły są domeną wielości ${ }^{2}$.

To jest istota woli mocy, szczególnie rozpoznawalna u żywej istoty: pęd ku „zewnętrznemu światu”, zdobycie otaczającego świata, pewna asymilacja świata związana z dążeniem do wzmocnienia żywej perspektywy, którą jest, i z przekształceniem samej siebie. Otóż takie przedłużenie siebie czy rzutowanie siebie każdej żywej istoty na zewnątrz jest całkowicie analogiczne w przypadku działania i myślenia ludzkiego. Zarówno w życiu prywatnym, jak i w zjawiskach społecznych Nietzsche bez trudu pokazuje, m.in. za moralistami XVII wieku, że wszelka działalność ludzka może być postrzegana jako próba wzmocnienia i propagowania własnego punktu widzenia, perspektywy, którą jesteśmy, poprzez jej rozszerzenie na jak największą liczbę ludzi i ukształtowanie rzeczywistości według niej. Na przykład moralność ustanawiająca równość między ludźmi i walkę z cierpieniem jako wartości centralne zakłada pewną ideę człowieka, pewien model człowieka: człowieka „dobrego”. Bycie moralnym nie oznacza jedynie prostego przestrzegania zasad, jest również sposobem na propagowanie przez nas tego modelu człowieka z powodów, których sami nie znamy do końca (np. Nietzsche widzi u przeciętnego człowieka moralnego przede wszystkim wolę utwierdzania racji i dumy przeciętnego człowieka właśnie wobec roszczeń mocnego człowieka).

Musimy zatem wskazać na istotną różnicę między Ja świadomym i racjonalnym, na poziomie którego wierzymy, że działamy zgodnie z pewnymi wartościami i ideami, pewnymi uświadomionymi motywami, a nieświadomą Jaźnią (u Nietzschego: das Selbst ${ }^{3}$ ), czyli zespołem uczuć, które głęboko uwarunkują nasz sposób postrzegania świata, a w szczególności wybór wartości i centralnych idei naszej wizji świata ${ }^{4}$ Istota człowieka tkwi mniej w jego świadomym umyśle niż w żywym zbiorze emocji, pragnień i w dużej mierze nieświadomych kategorii, który używa umysłu jako środka wyrazu. To Jaźń, która nami rządzi, jest korzeniem

2 „Wszelka jedność jest jednością tylko jako organizacja i współgranie - nie inaczej niż [tak], jak [dowolna] ludzka wspólnota jest jednością - ergo przeciwieństwem atomistycznej anarchii: tworem [opartym na] panowaniu więc, który znaczy jedno, ale nie jest jednym". Friedrich Nietzsche, Dzieła wszystkie. Notatki z lat 1885-1887, t. 12, przeł. Marta Kopij, Grzegorz Sowinski (Łódź: Wydawnictwo Officyna, 2012), 122. Cytuję dalej jako: N12.

3 Zob. np. Za-I-Veraechter - Also sprach Zarathustra I: Von den Verächtern des Leibes, dostęp 23.02.2021, www.nietzschesource.org.

4 Por. Friedrich Nietzsche, To rzekł Zaratustra. Ksiażka dla wszystkich $i$ dla nikogo, przeł. Sława Lisiecka, Zdzisław Jaskuła (Madryt: Mediasat Group, Biblioteka Gazety Wyborczej 19, 2005), 29-30. 
naszego spojrzenia na świat, naszego sposobu interpretowania i kształtowania doświadczenia, nadawania światu sensu ${ }^{5}$. Jaźń decyduje więc o tym, jak „przywłaszczamy” sobie świat, jak go oswajamy, starając się wzmocnić własną perspektywę i odcisnać ją na innych istotach.

Jednakże według Nietzschego podstawowa czy „zdrowa” tendencja życia nie polega przede wszystkim na zwiększaniu swojej władzy istota żywa chce zwiększać swoją moc, tzn. rozwijać moc Jaźni, którą jest, i w konsekwencji przekroczyć samą siebie. Wzrost wpływu i władzy w świecie może zwiększać radość i dawać pewne poczucie mocy, ale nie jest jeszcze równoznaczny z prawdziwą radością wypływającą z przekraczania siebie. Nie chodzi w nim o przemianę sytuacji zewnętrznej człowieka, jak w przypadku posiadania czy panowania technicznego, ale o przemianę wewnętrzną: Jaźń rośnie, uczestniczy w czymś większym od siebie. Człowiek zdaje się zasadniczo dążyć do przywłaszczenia sobie świata lub zjednoczenia się z nim, z jak największą liczbą istot, zgodnie z naturą własnej i osobliwej Jaźni, ale to zjednoczenie może nastąpić tylko wtedy, gdy Jaźń jest zdolna do rozszerzenia się na świat, do przekroczenia samej siebie poprzez niego.

W jaki sposób możemy przekroczyć samych siebie? Jak dokonuje się poszerzenie perspektywy, którą jesteśmy, i nasze prawdziwe zjednoczenie ze światem? To właśnie wtedy, gdy ta perspektywa jest żywa, stara się ona rozwijać, doskonaląc swoje kształtowanie (lub „organ-izowanie”) świata. Czy będzie to znacząca czynność życia codziennego nadająca mu nowy wymiar, czy wymysł polityka, poety lub filozofa, kształtowanie to możemy nazwać „dziełem”, twórczością artystyczną w szerszym znaczeniu, o ile człowiek nie dąży przez nie jedynie do osiągnięcia celów utylitarnych lub urojonych, ale do wyrażenia uczuć, umiłowanych dla nich samych. Ekspresja głębokich emocji Jaźni jest dla niej jednocześnie drogą do ekspansji, do zjednoczenia ze światem i do wzrostu.

To właśnie ten wzrost Jaźni chciałbym tutaj opisać, pokazując, jak świadczy on o jej największej mocy, dzięki „,artystycznemu” tworzeniu sensu: przede wszystkim tworzy „żywioł", w którym podmiot jest nierozerwalnie związany ze swoim przedmiotem (nazywam ten stan „stanowieniem ciała ze światem”). Żywioł ten jest tym samym miejscem tworzenia sensu na radykalnym poziomie, ponieważ same pojęcia podmiotu i przedmiotu są w tym żywiole według Nietzschego niestabilne ${ }^{6}$,

5 Nietzsche, N12, 164: „Kto dokonuje wykładni? - Nasze afekty”.

6 Por. Nietzsche, N11, 245-246: „«Doświadczenie», tj. wynik wszystkich tego typu reakcji, w których reagowaliśmy na coś poza nami bądź w nas. - Zespoliliśmy nasze reakcje z rzeczą, która na nas zadziałała". Por. również Friedrich 
stają się raczej ogniskami sensów niż stałymi bytami czy pojęciami, wciągając w swój ruch inne pojęcia/rzeczywistości fundamentalne (właśnie wtedy trudno odróżnić pojęcia od rzeczywistości) w dionizyjskim tańcu stawania się.

\section{Stanowienie ciała ze światem. Dzieło}

Samą świadomością nie moglibyśmy stanowić jedności ze światem: poprzez nią jesteśmy tylko widzami świata, świat jest dla świadomości ob-iektem, przed-miotem. Przedmiot jest przed nami, istotowo na zewnątrz nas. Inaczej z emocjami, poprzez które jesteśmy zarówno w świecie, jak i częścią świata. Emocje są tym, co zdoła się w nas zjednoczyć nieodróżnialnie ze światem, w taki sposób, że sam świat, w który emocje się rzutują, wydaje się u twórczego człowieka zawierać więcej emocji i znaczeń niż sam człowiek, który rzutuje te emocje w niego ${ }^{7}$. Im głębsza jest jedność ze światem, tym głębsze i żywsze są emocje, które człowiek rzutuje w niego.

Ten proces można nazwać „stanowieniem ciała ze światem”. Jest to proces, w którym umysł i ciało stają się jednym, kiedy sens wydaje się obecny zarówno w „zewnętrznym" przedmiocie, jak i w "podmiocie”, przy czym te dwa antynomiczne pojęcia stają się jako takie nieważne ${ }^{8}$.

Jak przebiega ten proces, którego zwieńczeniem staje się zasadniczy rezultat - wypracowanie dzieła w szerokim znaczeniu? Przede wszystkim stanowienie ciała ze światem jako takie implikuje wrażliwość „,arty-

Nietzsche, Pisma pozostałe 1876-1889, przeł. Bogdan Baran (Kraków: Inter Esse, 1994), 39: „, [...] coś przeważającego chwilowo czynimy instynktownie całym ego i wszelkie słabsze popędy stawiamy perspektywistycznie dalej, czyniąc z tego całe Ty lub «to»".

7 „W stanie tym wszystko ubogacamy, z własnej pełni; wszystko, co widzimy, co chcemy widzieć, widzimy jako coś wezbranego, stłoczonego, potężnego, przeładowanego siłą”. Friedrich Nietzsche, „Eskapada niewczesnego”, w: Friedrich Nietzsche, Zmierzch bożyszcz, czyli jak filozofuje się młotem, przeł. Grzegorz Sowinski (Kraków: Wydawnictwo Uniwersytetu Jagiellońskiego, 2013), 94.

8 Por. Nietzsche, N12, 189: „Musimy chcieć przeżywać wielkie problemy ciałem i duszą", oraz Friedrich Nietzsche, NF-1880,6 [80], przekład własny, dostęp 8.03.2021, www.nietzschesource.org: „,jesteśmy kosmosem, o ile go zrozumieliśmy lub marzyliśmy o nim. Drzewa oliwne i burze stały się częścią nas, podobnie jak giełda i gazeta” ([,Nicht nur Gott, sondern alle Wesen, die wir anerkennen, nehmen wir, selbst ohne Namen, in uns hinein:] wir sind der Kosmos, soweit wir ihn begriffen oder geträumt haben. Die Oliven und die Stürme sind ein Theil von uns geworden: die Börse und die Zeitung ebenso"). 
styczną": zdolność głębokiego rozpoznania siebie w wielu rzeczach, nawet w kształtach, dźwiękach itd., bycie giętką tożsamościa, dominującą siłą otwartą na wielość, poszukującą wielości. Nasz „,środek” nie jest wówczas w nas w stałej formie, ale pulsuje w mieszance nas i rzeczy. Tożsamość jest paradoksalnie pomiędzy, w stawaniu się. Taki stan wrażliwości wymaga wtedy od Jaźni wysiłku, aby stworzyła czy odkryła jedność tego, co różnorodne, co kocha i czym w pewien sposób jest. To oznacza dążenie do zebrania emocji przez giętką siłę dominująca, czego wynikiem jest „dzieło”. Gdy emocje te są silnie zjednoczone, powstaje charakterystyczne dla każdego dzieła zjawisko stopienia się sensu z materia, dzięki któremu dokonuje się najpełniejsze stanowienie ciała ze światem.

\section{a) „Artystyczna" wrażliwość: głębokie rozpoznawanie siebie w wielości}

Stanowienie ciała ze światem zakłada szeroko rozumianą wrażliwość artystyczna, ponieważ jest ono nierozerwalnym i twórczym połączeniem Jaźni z częścią świata „zewnętrznego”. Poprzez swoją wrażliwość Jaźń jest nie tylko połączona z wieloma rzeczami, ale także rozpoznaje w nich siebie na głębokim poziomie, tak że jej tożsamość staje się giętka i wieloraka. Jest tak w przypadku każdego działania, które ma istotne pokrewieństwo z działaniem artysty: to, co nas porusza, przedłuża Jaźń, rozbudza żywioł, który wykracza poza ograniczone Ja9. Przypisywane w ten sposób bytom wartości czy emocje są w dużej mierze projekcjami Jaźni na nie, dlatego są „,iluzjami”, ,sztuką” (emocje i wartości nie są w rzeczach samych). Jednak tylko dzięki tej sztuce i ciepłu miłości człowiek może odsłaniać aspekty rzeczy, których obiektywna myśl nie dostrzega. „Sztuka” jest, przynajmniej dla Jaźni, środkiem wyrażania siebie, a więc umacniania i w pewnej mierze poznawania siebie. W końcu rzeczy lub istoty zawsze zawierają w sobie nieredukowalną różnicę, która sprawia, że Jaźń, przez sam fakt, że rozpoznaje w nich siebie, musi nieustannie starać się przekroczyć siebie, aby je zintegrować.

O tym, że taki związek między człowiekiem a światem jest możliwy, świadczy przykład artystów w ścisłym tego słowa znaczeniu. Skoro artysta jest zjawiskiem najbardziej charakterystycznym dla funkcjonowania życia ${ }^{10}$, można przyjąć, że w pewnych chwilach proces ten zachodzi w ży-

9 Por. np.: „W tym żywiole kąpał się i pławił duch antyczny”, Friedrich Nietzsche, Radosna wiedza, przeł. Małgorzata Łukasiewicz (Gdańsk: Wydawnictwo Słowo/obraz terytoria, 2008), 94.

10 „Fenomen «artysta» najłatwiej daje się przejrzeć: od jego strony spojrzeć na podstawowe instynkty mocy, natury itd.! [A] także religii i moralności!". Nietzsche, N12, 140. 
ciu każdego człowieka, ale w sposób zbyt niedostrzegalny i niejasny, aby zmuszał go do stworzenia dzieła. Dla artystów, jak np. Wagner, krajobrazy znaczą coś, co starają się oni wyrazić w sztuce. Ale żeby to poczuć, musieli odczuwać emocje, które zdawały się emanować tak samo z rzeczy, które je wzbudzały, jak i z własnych Jaźni ${ }^{11}$. „To, co rzeczy znaczą”, co nam o sobie „mówią”, łączy je nierozerwalnie z Jaźnią. W końcu jest to rodzaj wezwania, wymaganie ekspresji, które pojawia się na skraju emocji Jaźni lub w ich największej głębi, zmuszając ją do poszukiwania i wymyślania własnego języka. Działanie polegające na słuchaniu i wyrażaniu rzeczy jest przekształcającym przedłużeniem Jaźni, która musi zanurzyć się w rzeczach, zapomnieć o sobie i o swoich zwykłych kategoriach, aby usłyszeć, jakie emocje rzeczy w niej wzbudzaja, a więc i jakie nowe sensy rodzą się w niej "pod ich wpływem”.

Największe emocje wzbudza w nas jednak najczęściej obecność innych ludzi, np. pod względem moralnym. Także tutaj możemy odczuwać nasze więzi z innymi jako uczestnictwo człowieka w żywiole, które wykracza poza jednostki. Człowiek czuje w pewien sposób, że ,jest” innymi, i szuka w nich tego, ",co chce zostać uczynione”; są oni źródłem wezwania, wskazówką jego nieuświadomionego przeznaczenia. Moralność sama w sobie może być zatem rodzajem szeroko pojętej sztuki, żywym tworzeniem sensu, w przeciwieństwie do moralności najczęściej krytykowanej przez Nietzschego, moralności bezosobowego posłuszeństwa regułom, która świadczy o niskich pragnieniach - strachu, chęci podporządkowania się, chęci pośredniego chwalenia siebie i umniejszania silnych.

W końcu sama reakcja na dzieła ludzkie jest często źródłem płodnego dzieła, sama w sobie staje się potencjalnie inną formą dzieła. Możemy rozpoznać siebie w stworzonych przez nas bytach, które jednak zdają się mieć własne życie, dzięki czemu artysta uczestniczy w szerszym, wykraczającym poza niego żywiole. Dzieje się tak już w szeroko rozumianym dziele: np. dziecko jest dla matki jej dziełem, które jednak posiada autonomię i dzięki temu pozwala jej uczestniczyć w całości większej od niej samej. Razem tworzą nierozerwalną całość różnych bytów, żywioł, w którym oboje uczestniczą i który ich przekracza. W tym matka jest podobna do każdego stwórcy ${ }^{12}$. Tworzy on dzieła i byty fikcyjne, które nie

11 Por.: „Zanurza się więc w zorzę poranna, w las, we mgłę, w przepaści, w wyżyny górskie, w zgrozę nocy, w blask księżyca i dostrzega w nich żądze tajemne: i one chcą dźwięczeć”. Friedrich Nietzsche, „Ryszard Wagner w Bayreuth”, w: Friedrich Nietzsche, Przypadek Wagnera, przeł. Maria Cumft-Pieńkowska (Toruń: Wydawnictwo Uniwersytetu Mikołaja Kopernika, 2004), 69.

12 Por. Nietzsche, Radosna, 91. 
są prostymi przedłużeniami jego samego i nie są jedynie przedstawieniami jego świadomości, mają one pewną autonomię, własne życie ${ }^{13}$. To właśnie zjednoczenie $z$ nimi, które odczuwane jest jako nierozerwalne, sprawia, że twórca aktywnie uczestniczy w żywiole, który go przerasta. Tak jest par excellence w przypadku Homera.

„Poeta przez to jest tylko poeta, że widzi się otoczonym postaciami, które przed jego oczyma żyją i działają i w których najwewnętrzniejszą istotę wnika” ${ }^{14}$. „Dlaczego Homer opisuje naoczniej niż inni poeci? Ponieważ więcej patrzy"15. „,...] trzeba mieć tylko zdolność widzieć nieustannie grę żywą i żyć nieustannie w otoczeniu rojów duchów, a jest się poetą; trzeba czuć tylko popęd do samoprzemiany i przemawiania przez cudze ciała i dusze, a jest się dramaturgiem”16. „Wzruszenie dionizyjskie może udzielić całemu tłumowi tej zdolności artystycznej widzenia się w otoczeniu takiego roju duchów, z którymi wewnętrznie czuje się jednym"17.

Artysta jest bardziej niż inni ludzie ekspresyjny, ponieważ „widzi więcej”, a widzi więcej dlatego, że „,jest" bardziej, jego byt jest jeszcze żywa potencjalnością różnych form, stąd głęboka i nieopisana jedność, która łączy go z jego tworami (przypomina to rodzaj „upojenia”, gdyż zwykły i racjonalny podmiot wydaje się zniesiony i uczestniczy z entuzjazmem w szerszym żywiole). To właśnie szersza potencjalność jego Jaźni pozwala mu tworzyć różne postaci i wcielać się w nie. Nie jest tylko jednostka, ponieważ dzięki własnej wrażliwości jego życie uczestniczy w wielu życiach albo inaczej: u niego iluzja wiary w jednostkę jest oczywista, skoro wielość stworzonych przez niego postaci wskazuje na wielorakość samej tożsamości artysty. Tworzone dzieła i istoty krystalizują różne aspekty tego samego, fundamentalnego spojrzenia na świat, wzmacniają głęboką niepowtarzalność Jaźni, wyrażając ją w wielości (w różnych postaciach). Z tego powodu można stwierdzić wraz z Nietzschem, że moc tkwi przede

13 Por. również: „gdzie się pojawiają [stwórcy «państwa»], tam wkrótce wyłania się coś nowego, władczy twór, który żyje, w którym części i funkcje są rozgraniczone i powiązane wzajemnie, w którym nie znajdzie miejsca nic, do czego najpierw nie dołożono by «sensu» wiążącego się z całością". Friedrich Nietzsche, Z genealogii moralności, przeł. Grzegorz Sowinski (Kraków: Wydawnictwo Uniwersytetu Jagiellońskiego, 2011), 86.

14 Friedrich Nietzsche, Narodziny tragedii z ducha muzyki, przeł. Leopold Staff (Warszawa: Nakład Jacóba Mortkowicza, 1907), 60.

15 Tamże, 61.

16 Tamże. Por. również: „człowiek w stanie dionizyjskim łatwo dokonuje metamorfozy, nie jest zdolny nie reagować". Nietzsche, Zmierzch, 95.

17 Tamże. 
wszystkim w zdolności odczuwania, ponieważ emocje są źródłem stworzenia sensu. Zdolność odczuwania z kolei jest zależna od siły zmysłów. "Siła i moc zmysłów - to jest najbardziej istotną charakterystyką udatnego i pełnego człowieka"18.

\section{b) Synteza, dzieło: zebranie wielości sił przez giętką siłę dominującą}

Płodne stanowienie ciała ze światem wzbudza w człowieku chęć utrzymywania i przedłużenia jego rezonansu, ponieważ rzutowanie Jaźni na bardzo różne rzeczy przyczynia się do jej samookreślenia. Emocje obecne w „ustanawianiu wspólnego ciała” nie są wynikiem zewnętrznego działania przedmiotu na wewnętrzny podmiot, lecz stanowią mieszankę, w której podmiot i przedmiot stają się nieodłączne. Jaźń, utożsamiając się z tyloma różnymi rzeczami, znajduje się „w środku” wielości, co zmusza ją do zadania sobie milczącego pytania o własną tożsamość (i odwrotnie, wydaje się, że poprzez nią rzeczy same poszukują własnej tożsamości). Odtąd Jaźń „podbija” świat, wyruszając na podbój samej siebie. Gdy dysponuje środkami wyrazu, poszukiwanie jedności przybiera formę działań lub stworzonych rzeczy, „,dzieł” w szerszym sensie, które ucieleśniają wyrażają czynią trwałymi i wzajemnie się wzmacniającymi wiele emocji, co odpowiada ogólnemu dążeniu życia do wzrostu mocy: „, [...] natura syntetyczna jest wyższą naturą"19.

Aby osiągnąć tę subtelną, nową i żywą jedność, Jaźnie twórcze poszukują dla każdego dzieła (i dla swojego życia jako dzieła) „siły dominującej” (emocji) zdolnej zjednoczyć wiele innych. Szukają linii większego wzrostu, starając się utrzymywać w sobie całość emocji doświadczenia, aby pozwalać im rezonować, ponieważ wiedza, że wtedy wynurza się pełny sens, odwrotnie niż w treściach świadomości, które zawsze są upraszczające ${ }^{20}$.

18 Nietzsche, N12, 190.

19 Tamże, 70.

20 Tamże, 62-63: „Wszystko, co dociera do świadomości, jest ostatnim ogniwem łańcucha, swego rodzaju zakończeniem. To jedynie pozór, że jakaś myśl stanowi bezpośrednio przyczynę jakiejś innej myśli. Właściwie powiązane wewnętrznie dzianie się przebiega poniżej poziomu naszej świadomości: występujące w niej szeregi i sekwencje uczuć, myśli itd. stanowią symptom właściwego dziania się! - Pod każdą myślą skrywa się jakiś afekt. Wszelka myśl, wszelkie uczucie, wszelka wola nie rodzą się za sprawą jakiegoś jednego, określonego popędu, lecz są globalnym stanem, całą powierzchnią całej świadomości i rezultatem chwilowego ustalenia się stosunku mocy pomiędzy wszystkimi konstytuującymi nas popędami [...]. Każda następna myśl jest znakiem, który sygnalizuje, jak w międzyczasie zmodyfikował się ten globalny układ mocy". 
Wsłuchują się w całość emocji w poszukiwaniu tego, czego chce dominująca w nich siła, „w taki sam sposób muzyk w ciemności znajduje właściwy klawisz"21. Szukają dominującej siły w swoim życiu, ale poprzez fraktale własnych najróżniejszych dzieł. Za każdym razem konkretna emocja chce znaleźć swój wyraz i zorganizować dzieło (wpoić w nie pewną duszę), które wzmacnia głębokie emocje Jaźni, rezonując z nią. Twórca stara się zagęścić doświadczenie ${ }^{22}$, którego każda istotna część wzywa jak nuta, pragnąca stworzyć symfonię z innymi.

Filozof usiłuje powtórzyć w samym sobie wszechbrzmienie świata i wydobyć je z siebie w pojęciach; choć wzrokowy jak artysta plastyk, współczujący jak człowiek religijny, tropiący cele i związki kauzalne jak naukowiec, choć czuje się wezbrany aż po makrokosmos, zachowuje on przy tym trzeźwość chłodnego traktowania siebie jako odbicia świata $[\ldots]^{23}$.

Umiejętność scalenia życia, doświadczenia, emocji i idei w najbardziej żywy sposób skutkuje maksymalnym zagęszczeniem, które powoduje zmianę jakościową, żarzenie się: sens jest nierozerwalnie związany z „materią” i jej forma, następuje stopienie się doświadczenia w stylu. „Istotnie, zda się, by przypomnieć stwierdzenie Zaratustry, że to same rzeczy przychodzą i ofiarują się na przenośnię [... $]^{\prime 24}$.

Człowiek „syntezy” łączy naturalnie intelekt z ciałem, dzięki czemu każde z nich uzyskuje maksimum swojej mocy. W okresie nowożytnym, gdy panuje pozór samodzielności rozumu i świadomości, wzorem moga być dla niego Grecy. W szczególności język nie jest tak samowystarczalny, jak się wydaje, poprzedzające go od wieków „nie-werbalne” formy wyrazu są nadal bliższe źródła sensu. Dlatego my, nowożytni, rozumiemy z trudem dawną ekspresję myśli, zakładając z powodu perspektywistycznej iluzji, że tkwi ona przede wszystkim w świadomości. W rzeczywistości

21 ,[Die Bildung ist nicht nothwendig eine begriffliche, sondern vor allem eine anschauende und richtig wählende:] wie der Musiker richtig im Finstern greift". Friedrich Nietzsche, NF-1872,19[299], dostęp 11.03.2021, www.nietzschesource.org.

22 Por. Nietzsche, N12, 147-148: „Można wykazać pełną analogię między upraszczaniem i komprymowaniem niezliczonych doświadczeń w tezy generalne oraz powstawaniem komórki nasiennej, która zawiera w sobie skrót całej przeszłości [...] dwie te strony można najwyraźniej jako paralelne zademonstrować w przypadku «dzieła sztuki»".

23 Friedrich Nietzsche, „Filozofia w tragicznej epoce Greków”, w: Friedrich Nietzsche, Pisma pozostałe 1862-1875, przeł. Bogdan Baran (Kraków: Inter Esse, 1993), 121-122.

24 Friedrich Nietzsche, Ecce homo: jak się staje, czym się jest, przeł. Bogdan Baran (Kraków: Wydawnictwo Baran i Suszczyński, 1995), 100. 
sposób przedstawienia idei lub wykonania działania pełniej wyrażają emocje, a zatem i sensy, o czym Grecy wiedzieli instynktownie, nadając zasadnicze znaczenie ogólnemu porządkowi i stylowi, a nie abstrakcyjnym ideom. „Nie myśl jest podstawą podania, jak sądzą dzieci sztucznej kultury, ale podanie samo jest myśleniem. Daje wyobrażenie świata, przedstawiając dzieje, czyny i cierpienia" 25 .

Powołaniem artystów jest odnalezienie więzi z żywymi źródłami sensu, pod nawarstwieniem uświadomionych wyrazów, które poprzez bezwładny ruch specjalizacji oddalały się coraz bardziej od źródła. Najwybitniejszym przykładem "powrotu do źródła” jest w tym wypadku również muzyka, łącząca nieodróżnialne dźwięki, emocje i sens: „Wagner zmusił mowę, żeby wróciła do stanu pierwotnego, gdzie niemal nie myśli ona pojęciami, gdzie sama jeszcze jest poezją, obrazem i uczuciem" 26 .

\section{Przekroczenie Jaźni przez samą siebie i głębia właściwa wszelkiemu twórczemu stanowieniu ciała}

Jeśli człowiek usiłuje zawłaszczyć świat, to najlepiej mu się to udaje, gdy rzutuje na świat to, co w nim najgłębsze: najgłębsze pragnienia i emocje, leżące u podstaw spojrzenia na świat, jakim jest pewien osobliwy smak ${ }^{27}$. Smak znajduje się i wyraża jedynie poprzez tworzenie, poprzez odnajdywanie go stopniowo w dziele, w żywym połączeniu Jaźni i świata zrealizowanym przez dzieło. Dzieło jest więc środkiem do „stworzenia” Jaźni przez nią samą ${ }^{28}$, co dobrze ilustruje Nietzscheańskie pojęcie mocy, ponieważ nie ma większej mocy niż moc stworzenia siebie, czyli moc przekroczenia siebie, czy to poprzez własny jednostkowy wysiłek twórczy (własny „żywioł”), czy poprzez udział w żywym i wyższym żywiole stworzonym przez „naturalne” i afirmacyjne społeczeństwo.

25 Nietzsche, Przypadek, 65.

26 Tamże, 66.

27 Nietzsche, N12, 86: „U podstawy jest coś niepoddającego się zmianie: granit fatum, [granit] z góry określonej decyzji w stosunku do nas, podobnie prawo do określonych problemów, ich piętno wypalone na naszym nazwisku". Por. również Nietzsche, Radosna, 69: „[...] poglądy, ze wszystkimi dowodami, kontrargumentami i całą intelektualną maskaradą, są tylko objawami zmiany smaku $[\ldots]^{\prime \prime}$.

28 Por. Nietzsche, Ecce, 51: „Stawanie się, czym się jest, zakłada, że w najmniejszym stopniu nie przeczuwa się, czym się jest". 
Aspekt ponad-osobowy ${ }^{29}$ twórczych dzieł pochodzi częściowo z faktu, że tworząc je, twórca tworzy też siebie. Będąc w trakcie "tworzenia się", nie wie w sposób świadomy i racjonalny, kim jest, dokąd zmierza ${ }^{30}$. Mówienie o sobie jako o osobie nie ma już wówczas większego znaczenia: możemy tylko stwierdzić istnienie sił, które świadomość pragnie wyrażać i pasożytować na nich, ale nie wiemy, czym są i czym „chcą" być te siły, mimo że w procesie tworzenia wymagania i intuicje Jaźni są nader precyzyjne, jasne i stanowcze ${ }^{31}$. Nie mamy już do czynienia ze znanym autorem, lecz z nieznaną siłą sprawcza, nie z osoba, lecz z Płaszczyzną ${ }^{32}$.

Jeśli w doświadczeniu artysty chwieją się tożsamość i centralna antynomia podmiot/przedmiot, w konsekwencji wprawiają one w chwianie się wszystkie inne fałszywe antynomie i ożywiają podstawowe pojęcia-rzeczywistości i antagonizmy, które dotyczą istotnej sytuacji umysłu i sensu w świecie: czas, śmierć, sens i absurd, miłość ludzka, obojętność świata itd. Możemy je naprawdę dostrzec jedynie poprzez wyczucie ludzkiej słabości wobec wszechobecności chaosu (to, że twórca jest w stanie stawania się, oznacza, że jest zagrożony w swoim bycie, co pociąga za sobą poczucie radykalnej słabości) ${ }^{33}$. Myśl twórcy rekonstruuje lub ożywia własną perspektywę, utrzymując w stanie ciągłego tworzenia "definicje" i relacje tych podstawowych rzeczywistości względem siebie wzajemnie. Możemy stwierdzić, że myślenie jest żywe, gdy wykonuje tę pracę "tworzenia”, zmysłową pracę syntezy i odróżnienia, działając w żywiole tworzenia sensu. Jednak sam fakt stworzenia czegoś nowego

29 Czy „obiektywny”, por. Friedrich Nietzsche, Narodziny tragedii, przeł. Grzegorz Sowinski (Kraków: Wydawnictwo Uniwersytetu Jagiellońskiego, 2011), 103.

30 To jest według Nietzschego istotna cecha szlachetności, por. Nietzsche, Radosna, 79.

31 Friedrich Nietzsche, Poza dobrem i złem, preludium do filozofii przyszłości, przeł. Grzegorz Sowinski (Kraków: Wydawnictwo Uniwersytetu Jagiellońskiego, 2012), 118: „Każdy artysta wie, jak daleki od folgowania sobie jest w swym najbardziej «naturalnym» stanie: w swobodnym porządkowaniu, ustalaniu, dysponowaniu, kształtowaniu, gdy przychodzi chwila «natchnienia», jak ściśle i subtelnie daje posłuch tysiącom praw, które swą twardością i stanowczością szydzą z wszelkiego formułowania za pomocą pojęć (w porównaniu z nimi nawet najbardziej stałe pojęcie jest płynnym, wielorakim, wieloznacznym tworem). By jeszcze raz powtórzyć: jak się zdaje, najistotniejszy, «w niebie i na ziemi», jest posłuch, który musi długo trwać i zmierzać w jednym kierunku [...]".

32 Por. Gilles Deleuze, Félix Guattari, Co to jest filozofia?, przeł. Paweł Pieniążek (Gdańsk: Wydawnictwo Słowo/obraz terytoria, 2000), 43-70.

33 Por. Nietzsche, Radosna, § 48, 76, oraz Nietzsche, Przypadek, 40: „Nie ma większej rozkoszy nad tę świadomość, że myśl tragiczna odrodziła się w świecie. Gdyż rozkosz ta jest rozkoszą nadosobistą i ogólną jest radością ludzkości ze związku poręczonego oraz z postępu ludzkiego w ogóle". 
jest w twórczości mniej decydujący niż sam stan, w którym znajduje się myśl, gdy musi zdefiniować rzeczy „na ślepo”, nie opierając się na znanej klasyfikacji, a na własnej wrażliwości, która wyraża się i częściowo konstytuuje poprzez własny wyraz. „Najważniejsze, że tego rodzaju zmiana jest nie tylko sposobem myślenia, ale i usposobienia [...] - najwyższy stopień samookreślenia $[\ldots]^{\prime \prime 34}$. Naturalnie nie chodzi tu o czystą i abstrakcyjną świadomość racjonalną w sensie Kartezjańskiego cogito, lecz o percepcję najgłębszego korzenia sensu - żywiołu.

Twórcza Jaźń wie, jak tworzyć i kultywować żywioł, który nie jest tylko jej podstawą, ale ogólnie podstawą ludzkiej perspektywy. Ludzkim korzeniem sensu jest u każdego twórcy osobliwa miłość, która żyje $\mathrm{w}$ żywiole potencjalnych emocji, gdy nadawanie kształtu czemuś jest piękne i kochane samo w sobie jako nadawanie kształtu, władanie formą. W żywiole człowiek może odczuć swoją największą jedność ze światem, ponieważ doświadcza, że sama przyroda tworzy poprzez niego i w ten sam sposób co on. Takie zjednoczenie z przyrodą jest niesprowadzalne do skłonności „małego ego" 35 i do sentymentalizmu, ponieważ jest szerszym doświadczeniem życia, kondycji ludzkiej i ogólnej natury sensu.

Umiłowanie sensu jako takiego, dla głębokich emocji, poprzez które Jaźń rzutuje siebie we wszelkiego rodzaju "formy”, to afirmacyjna i „estetyczna” percepcja świata, którą Nietzsche określa jako dionizyjską i apollińską (ujawnia się ona najwyraźniej w swoich najbardziej spełnionych realizacjach, w sztuce $\mathrm{w}$ sensie ścisłym, ale Nietzsche ma pośrednio na myśli wszelkie twórcze działanie i percepcję). Dionizyjskie i apollińskie siły twórcze są ostatecznie przeciwstawne jedynie pod względem rytmu i głównego środka wyrazu: pierwsze angażują wszystkie zmysły w sposób gwałtowny, drugie skupiają się na spokojniejszym zmyśle wzroku, ale ich jedność jest zasadnicza, ponieważ w obu przypadkach chodzi o rodzaj „upojenia” i miłości ${ }^{36}$, które sprawiaja, że człowiek uczestniczy w żywym i radykalnym żywiole sensu. Twórca w szerszym znaczeniu tego słowa dzięki własnej wewnętrznej plastyczności ma w sobie zdolność do „rozpuszczenia” własnego istnienia w tym ogólnym i szerszym żywiole, uzyskując w ten sposób nowy wymiar własnego bytu.

34 Nietzsche, N11, 169.

35 Tym określeniem chciałbym zaznaczyć ograniczoność Jaźni, która nie pragnie przekroczenia siebie samej: „,[...] wasza Jaźń sama chce śmierci i odwraca się od życia. Nie potrafi już tego, czego najbardziej chce: tworzyć ponad siebie. [...] tak więc, wzgardziciele ciała, wasza Jaźń chce zejścia". Nietzsche, To rzekł Zaratustra, 30.

36 Nietzsche, Zmierzch, 94. 
Nasza znajomość sztuki jest więc w gruncie rzeczy iluzoryczna, ponieważ nie jesteśmy tożsami i nie stanowimy jedna z istota, która wieczyście delektuje się komedią sztuki jako jej jedyny twórca i widz. Geniusz zna wieczystą istotę sztuki tylko na tyle, na ile w akcie płodzenia artystycznego stapia się z praartysta, [który stworzył] świat ${ }^{37}$.

W tym jeszcze mitologicznym języku Nietzsche rozumie już jednak „praartystę świata” jako życie, jako nieskończenie szeroki element tworzenia sensu. Życie jako pierwotne źródło twórczości odczuwa się najgłębiej, gdy w ludzkiej twórczości akt nadawania sensu jest kochany dla niego samego, już poprzez sam wygląd jego kreacji ${ }^{38}$. Umysł pragnie nieskończonej rozległości, do której jest potencjalnie zdolny, dlatego dąży do tworzenia sensu. Poprzez swoje dzieła usiłuje wzmacniać symboliczne emocje wbrew chaosowi.

Znakiem, że osiągnęło się ten poziom głębi, jest potencjalność sensu, która ujawnia się wtedy w całej swej sile: np. tej samej melodii moga towarzyszyć różne słowa ${ }^{39}$ lub żywa filozofia może być reinterpretowana/reaktywowana ad infinitum. Sens wytryska ze źródła bez końca, nie zamyka się w swoim wyrazie, jak o tym świadczy empiryczne doświadczenie. Istotnie, ,to samo” źródło inspiracji może przybierać przeróżne formy i używać różnych środków wyrazu, co pokazuje, że jest pierwotne i niesprowadzalne do swojej ekspresji. Czerpiący z tej głębi człowiek wyrażający Jaźń jest „pełniejszy”40.

O głębi tego doświadczenia może świadczyć fakt, że ludzki byt i samo życie są fundamentalnie potencjalnością ${ }^{41}$, źródłem nieskończonych aktów twórczych. Kochać zdolność życia do tworzenia przez nas sensu to kochać istotę życia, afirmować życie. Pod tym względem Grecy są dla nas wzorem afirmacji, ponieważ życie jest przez nich bardzo wyraźnie kochane samo w sobie, poprzez perspektywę łączącą nierozerwalnie przenikliwy umysł i wrażliwe ciało. „«Wola», na apollińskim szczeblu, tak porywczo pragnie

37 Nietzsche, Narodziny (przeł. G. Sowinski), 108.

38 Por. Friedrich Nietzsche, Dzieła wszystkie. Notatki z lat 1887-1888, t. 13, przeł. Paweł Pieniążek (Łódź: Wydawnictwo Officyna, 2012), 39: „Artystą jest się za tę cenę, że coś, co wszyscy ludzie, którzy nie są artystami, nazywają "formą», odczuwa się jako treść, jako «samą rzecz»". Cytuję dalej jako: N13.

39 Por. Nietzsche, Narodziny, 109: „Zatem melodia stanowi pierwszy i ogólny moment, który z tej racji dopuszcza liczne obiektywizacje, w postaci licznych tekstów".

40 „O wielości języków (dzięki obrazom, dźwiękom) jako środku wypowiadania się pełniejszego człowieka". Nietzsche, N11, 84.

41 Por. Nietzsche, N12, 97: „[...] dotychczas był człowiek «nieustalonym zwierzęciem»". 
istnienia, Homerycki bohater tak bardzo czuje się jednością z nim, że nawet skarga przemienia się w pieśń pochwalną na jego cześć" ${ }^{42}$.

\section{Konkluzja}

Twórca jest istota, która może stać się jednym ze światem, pomnażać się na różne sposoby w świecie, rzutować siebie w niego. Tej radykalnej mocy nie osiąga się ani przez naukę, ani przez przyjemność (jest ona w swojej istocie bierna, niczego nie stwarza), ani przez piękne uczucia ${ }^{43}$, które przybierają formy moralne czy religijne, aby ukryć bezpłodność i brak prawdziwej miłości. Jaźń chce wzrastać, a nie pochlebiać ego formami czy formułami, które zadowalają tylko wyobraźnię, a nie wynikają z tworzenia sensu ${ }^{44}$.

Niniejszy artykuł chciałbym podsumować i zilustrować, cytując sporządzony przez Nietzschego opis jego własnego doświadczenia recepcji Carmen Bizeta. Opis tak mocnego przeżycia zawiera pośrednio, ale w jasny sposób, poszczególne etapy (lub elementy) tworzenia sensu: stanowienie ciała ze światem, syntezę, głębię.

I jeszcze raz: gdy przemawia do mnie Bizet, staję się lepszym człowiekiem. Również lepszym muzykantem, lepszym słuchaczem. Czy w ogóle można się lepiej wsłuchiwać? Moje uszy przenikają muzykę aż po jej źródła. Wydaje mi się, że przeżywam jej narodziny [...]. Jakie to dziwne! W zasadzie nie myślę o tym lub nie wiem, jak bardzo o tym myślę. Ponieważ w mojej głowie szybują całkiem inne myśli... Czy ktoś zauważył, że [...] ktoś tym bardziej staje się filozofem, im bardziej staje się muzykiem? Szare niebo abstrakcji jak przeszyte błyskawicami, dość światła dla lekkości rzeczy, nieomal uchwytne wielkie problemy, świat ogarnięty spojrzeniem jak z jakiejś góry - definiuję właśnie filozoficzny patos. I znienacka spadają mi z nieba odpowiedzi, mały grad lodu i mądrości, rozwiązanych problemów... gdzie jestem? Bizet czyni mnie płodnym ${ }^{45}$.

42 Nietzsche, Narodziny, 97.

43 Por. Nietzsche, N13, 414: „Wielkość muzyka nie mierzy się pięknymi uczuciami, jakie on wzbudza [...] mierzy się ją prężnością jego woli, pewnością z jaką chaos podlega jego rozkazowi artystycznemu i staje się formą [...]".

44 Por. Friedrich Nietzsche, Tako rzecze Zaratustra, ksiażka dla wszystkich i dla nikogo, przeł. Wacław Berent (Poznań: Vesper, 2006), 31: „Nie podoła ona [Jaźń] już temu, czego najserdeczniej pragnie: tworzyć ponad siebie już nie zdoła. Tego ona pragnie najbardziej, to jest całym jej żarem".

45 Friedrich Nietzsche, „Przypadek Wagnera”, w: Friedrich Nietzsche, Przypadek Wagnera, przeł. Rafał Michalski (Toruń: Wydawnictwo Uniwersytetu Mikołaja Kopernika, 2004), 88-89. 
Dobry słuchacz, dobry interpretator w ogóle, czyli „bardziej ludzki” człowiek w sensie tego cytatu („,staję się lepszym człowiekiem”), nie zadowala się biernym odbiorem zdarzenia, on je współtworzy (,'wydaje mi się, że przeżywam jej narodziny"), a jest to konieczne, aby dostrzegać najgłębszą warstwę zdarzenia, która nigdy nie wyraża się wprost $w$ formach, lecz poprzez nie. Dostrzegać ją to być wrażliwym na żywioł, z którego wyłaniają się formy, a który sam nie jest forma, lecz poruszającym się zbiorem uczuć i myśli o wielu potencjalnych sensach. Aby odczuć ten żywioł, trzeba „być" nim, samemu odczuwać dane uczucia, co oznacza, że następuje swoiste pozbycie się siebie lub „upojenie”, ponieważ nie pozostajemy poza przedmiotem, sami jesteśmy wydarzeniem. Stan, w którym człowiek jest zdolny odczuwać żywioł sensu, jest tym, co nazwałem wyżej „stanowieniem ciała ze światem”. Nie jest ono przedmiotem świadomego przedstawienia, jakkolwiek intensywne by ono nie było („Jakie to dziwne! W zasadzie nie myślę o tym lub nie wiem, jak bardzo o tym myślę. Ponieważ w mojej głowie szybują całkiem inne myśli..."), ale jest u słuchacza źródłem kolejnych aktów twórczych - form i myśli opartych na jego własnych doświadczeniach, wrażliwości. Jeśli żywioł muzyczny połączył się z żywiołem filozoficznym, to dlatego, że są one w zasadzie tym samym żywiołem tworzenia sensu. Powstaje w nim mieszanka - synteza między wydarzeniem a osobą tworzącą obrazy i myśli, które nie wydają się już przeżyciami osobistymi, ale istniejącymi same w sobie bytami $\mathrm{w}$ bezosobowym żywiole sensu: „I znienacka spadają mi z nieba odpowiedzi, mały grad lodu i mądrości, rozwiązanych problemów... gdzie jestem? Bizet czyni mnie płodnym". W tym zdaniu niewiedza o własnym bycie jest nierozerwalnie związana z płodnością a więc stanem, gdy tworzenie jest głębokie, to znaczy, gdy tworzone są sensy, które redefiniują samego twórcę i ogólniej - człowieka. Być może właśnie pojawienie się sensów $\mathrm{w}$ tym bezosobowym żywiole sprawia wrażenie, że nie wiemy już, gdzie jesteśmy, ponieważ myśli, które do nas docierają nie są postrzegane ani jako pochodzące bezpośrednio z zewnątrz, ani jako wymyślone przez nas samych, lecz jako pojawiające się pomiędzy, w stawaniu się, w którym sens jest nierozerwalną i żywą, giętką syntezą tego, co wewnętrzne i zewnętrzne.

$\mathrm{W}$ tym stanie widzenie tego, co nieskończenie małe, idzie w parze z widzeniem tego, co nieskończenie rozległe („,dość światła dla lekkości rzeczy ${ }^{46}$, nieomal uchwytne wielkie problemy, świat ogarnięty spojrze-

46 Zob. http://www.nietzschesource.org/\#eKGWB/WA-1, dostęp 8.03.2021: „das Licht stark genug für alles Filigran der Dinge; die grossen Probleme nahe zum Greifen”. Słowo „filigran” przywołuje dostrzeganie znaku wodnego pod światło. 
niem jak z jakiejś góry"), jak gdyby nie była możliwa żadna stabilna perspektywa ${ }^{47}$. Żywioł umieszcza nas w perspektywie jednocześnie głębokiej i wysokiej, bardzo subtelnej i bardzo szerokiej, ponieważ nie chodzi tu o zjawiskowe rzeczywistości, ale o ich radykalne sensy, a więc o rzeczywistości fundamentalne, „uniwersalne”, o „byty subtelne" 48 , przebiegające przez wszystkie istoty. Perspektywa fundamentalna przypomina brak perspektywy, jeśli weźmiemy pod uwagę jej zwykłe cechy (stabilny, określony punkt i pole widzenia), ponieważ jest ona zarówno sercem konkretnych bytów, jak i jedną z ich najbardziej ogólnych cech. Nie jest to pogląd intelektualny, lecz intuicyjne pojmowanie przedstawione za pomocą obrazów, ze wszystkimi doznaniami, jakie implikuje siła marzenia sennego. Bez określonej perspektywy wizja ta jest jednak przeciwieństwem chaosu, ponieważ jesteśmy tu w obliczu momentu rozwiązania, tworzenia, niesłychanej jasności myśli. Doznania tworzące tę ruchomą perspektywę i jej wyraz stanowią pewnego rodzaju taniec, który jest ideałem tworzenia filozofii według Nietzschego ${ }^{49}$.

\section{Bibliografia}

Astor Dorian. 2014. Nietzsche. La détresse du présent. Paris: Gallimard.

Deleuze Gilles. 1993. Nietzsche i filozofia, przeł. Bogdan Banasiak. Warszawa: Wydawnictwo SPACJA.

Deleuze Gilles, Guattari Félix. 2000. Co to jest filozofia?, przeł. Paweł Pieniążek. Gdańsk: Wydawnictwo Słowo/obraz terytoria.

Haar Michel. 1993. Nietzsche et la métaphysique. Paris: Gallimard.

Klossowski Pierre. 1996. Nietzsche i błędne koło, przeł. Bogdan Banasiak, Krzysztof Matuszewski. Warszawa: Wydawnictwo KR.

Nietzsche Friedrich. 1907. Narodziny tragedii z ducha muzyki, przeł. Leopold Staff. Warszawa: Nakład Jacóba Mortkowicza.

Nietzsche Friedrich. 1993. „Filozofia w tragicznej epoce Greków”. W: Friedrich Nietzsche, Pisma pozostate 1862-1875, przeł. Bogdan Baran, 103-180. Kraków: Inter Esse.

Nietzsche Friedrich. 1994. Pisma pozostałe 1876-1889, przeł. Bogdan Baran. Kraków: Inter Esse.

47 Por. Nietzsche, Narodziny, 90: „Śpiewając i tańcząc, człowiek ukazuje się jako członek wyższej wspólnoty - zapomina, jak chodzimy i jak mówimy, tańcząc, wzleci zaraz w przestworza". Por. również przypis 35, gdzie mowa jest o metaforze upojenia opisującej stan twórczy.

48 To określenie stworzone przez Jerzego Nowosielskiego w innym znaczeniu wydaje mi się wymowne w tym nowym kontekście.

49 Por. Nietzsche, Radosna, 283. 
Nietzsche Friedrich. 1995. Ecce homo: jak się staje, czym się jest, przeł. Bogdan Baran. Kraków: Wydawnictwo Baran i Suszczyński.

Nietzsche Friedrich. 2004. „Przypadek Wagnera”. W: Friedrich Nietzsche, Przypadek Wagnera, przeł. Rafał Michalski, 85-121. Toruń: Wydawnictwo Uniwersytetu Mikołaja Kopernika.

Nietzsche Friedrich. 2004. „Ryszard Wagner w Bayreuth”. W: Friedrich Nietzsche, Przypadek Wagnera, przeł. Maria Cumft-Pieńkowska, 23-84. Toruń: Wydawnictwo Uniwersytetu Mikołaja Kopernika.

Nietzsche Friedrich. 2005. To rzekt Zaratustra. Ksiażka dla wszystkich i dla nikogo, przeł. Sława Lisiecka, Zdzisław Jaskuła. Madryt: Mediasat Group, Biblioteka Gazety Wyborczej 19.

Nietzsche Friedrich. 2006. Tako rzecze Zaratustra, ksią̇ka dla wszystkich i dla nikogo, przeł. Wacław Berent. Poznań: Vesper.

Nietzsche Friedrich. 2008. Radosna wiedza, przeł. Małgorzata Łukasiewicz. Gdańsk: Wydawnictwo Słowo/obraz terytoria.

Nietzsche Friedrich. 2011. Nachlass. Pisma z lat 1884-1885, przeł. Grzegorz Kowal. Warszawa: Wydawnictwo Naukowe PWN.

Nietzsche Friedrich. 2011. Narodziny tragedii, przeł. Grzegorz Sowinski. Kraków: Wydawnictwo Uniwersytetu Jagiellońskiego.

Nietzsche Friedrich. 2011. Z genealogii moralności, przeł. Grzegorz Sowinski. Kraków: Wydawnictwo Uniwersytetu Jagiellońskiego.

Nietzsche Friedrich. 2012. Dzieła wszystkie. Notatki z lat 1885-1887, t. 12, przeł. Marta Kopij, Grzegorz Sowinski. Łódź: Wydawnictwo Officyna.

Nietzsche Friedrich. 2012. Dzieła wszystkie. Notatki z lat 1887-1888, t. 13, przeł. Paweł Pieniążek. Łódź: Wydawnictwo Officyna.

Nietzsche Friedrich. 2012. Poza dobrem i złem, preludium do filozofii przyszłości, przeł. Grzegorz Sowinski. Kraków: Wydawnictwo Uniwersytetu Jagiellońskiego.

Nietzsche Friedrich. 2013. „Eskapada niewczesnego”. W: Friedrich Nietzsche, Zmierzch bożyszcz, czyli jak filozofuje się młotem, przeł. Grzegorz Sowinski, 87-135. Kraków: Wydawnictwo Uniwersytetu Jagiellońskiego.

Safranski Rüdiger. 2003. Nietzsche: Biografia myśli, przeł. Dorota Stroińska. Warszawa: Czytelnik.

www.nietzschesource.org.

\section{Streszczenie}

Opierając się na rozwijanych przez Nietzschego pojęciach woli mocy i sensu, starałem się pokazać, pod jakim względem twórcza Jaźń świadczy według niego o największej ludzkiej mocy.

Jedną z najbardziej ogólnych cech mocy jest zdolność istoty do coraz lepszego zawłaszczania sił otaczającego ją świata. Stąd wyłaniają się trzy aspekty mocy: osobisty charakter tej integracji, rozległość zintegrowanego świata i przewyższanie samego siebie, które im towarzyszy. W przeciwieństwie jednak do „archaicznego” 
człowieka, który usiłuje narzucić swoje bycie światu poprzez władzę, odciskając swoje piętno w świecie jedynie poprzez wąska, zewnętrzną i niezmienną perspektywę swojej woli władzy, mocny człowiek potrafi zawładnąć siłami świata całą swoją istota, z całą swoją wrażliwością. Jest zdolny do głębokiego zjednoczenia się ze światem, co pozwala mu na integrację dzięki własnej sile plastycznej znacznie szerszego spektrum sił, ale też zmusza go do przewyższenia samego siebie, ponieważ $\mathrm{w}$ tym procesie integracji jego własna tożsamość zmienia się. Nadając nowy sens światu, zmienia sens własnego bytu. Ten stosunek do świata i ta moc charakteryzują twórcze jaźnie.

Słowa kluczowe: wola mocy, sens, Jaźń, twórczość

\section{Summary}

\section{The Power of the Creative Self in the Philosophy of Friedrich Nietzsche}

On the basis of Nietzsche's concepts of the will to power and meaning, I have tried to show why the creative Self is, according to the philosopher, the ultimate proof of the greatest human power.

One of the most general characteristics of power is our increasing ability to appropriate the forces of the world around us. Hence, three major aspects of power emerge: the personal nature of this integration, the vast dimensions of the integrated world, and the surpassing of oneself which is the inevitable consequence of the two. But, contrary to the "archaic" man trying to impose his existence in the world through domination, making an impact only through the narrow, external, and fixed perspective of his will to power, a truly powerful man is able to master the forces of the world with all his being and all his sensitivity. Thanks to his own "artistic" and flexible force, he is capable of becoming deeply reunited with the world, allowing for the integration of a much larger spectrum of forces. As his own identity changes during this integration process, he is forced to surpass himself. By giving a new meaning to the world, he is also changing the meaning of his own existence. Such attitude and such power are characteristic of creative Selves.

Keywords: will to power, meaning, Self, creativity 